\title{
PENANANAMAN NILAI KARAKTER SISWA KELAS IV SEKOLAH DASAR NEGERI 133 SELUMA MELALUI DONGENG "SAYEMBARA PANDAI TIDUR"
}

\author{
Raminem \\ Sekolah Dasar Negeri 133 Seluma \\ raminem2018@gmail.com
}

Submit, 13-06-2018 Accepted, 26-06-2018 Publish,29-06-2018

\begin{abstract}
ABSTRAK
Tujuan penelitian ini adalah sebagai bentuk inovasi pembelajaran menyenangkan bagi siswa khususnya siswa Sekolah Dasar Negeri 133 Seluma dalam belajar bahasa Indonesia. Penulis menggunakan metode kualitatif deskriptif. Kajian diambil dari hasil observasi dan pengalaman mengajar di kelas. Dengan analisis teks dogeng yang dikembangkan sebagai bahan ajar bagi siswa. Hasil penelitian menunjukkan tema yang terkandung dalam dongeng" Sayembara Pandai Tidur" yaitu ketekunan pemuda yang pndai tidur. Sedangkan amanat yang terdapat dalam cerita yaitu kita harus pandai memanfaatkan waktu luang dan tidak boleh membeda-bedakan antara si kaya dan si miskin. Nilai karakter yang ditemukan dalam dongeng tersebut adalah jujur, disiplin dan peduli sosial yang tinggi. Nilai-nilai karakter dalam dongeng atau cerita rakyat dari Bengkulu yang sering muncul berdasarkan cerita yang dianalisis sebanyak tiga cerita, yaitu karakter disiplin dan peduli sosial. Oleh karena itu, karakter disiplin dan peduli sosial sangat cocok ditanamkan untuk anak-anak.
\end{abstract}

Katakunci: Penanaman, Karakter, Dongeng.

\begin{abstract}
The purpose of storytelling as a form of learning innovation fun for students, especially elementary school students 133 Seluma in learning Indonesian language. The author uses descriptive qualitative methods. The study was taken from the observation and teaching experience in the classroom. With dogeng text analysis developed as a learning material for students. The results show the theme contained in the fairy tale of "Sleepy Swarm" is the persistence of sleeping youth. While the mandate contained in the story that we must be good at using free time and should not distinguish between the rich and the poor. The value of the characters found in the fairy tale is honest, disciplined and socially responsible. Values of characters in fairy tales or folklore from Bengkulu that often appear based on the story analyzed as much as three stories, namely the character of discipline and social care. Therefore, the character of discipline and social care is very suitable implanted for children.
\end{abstract}

Keywords: Planting, Character, Fairy Tale. 


\section{PENDAHULUAN}

Saat ini krisis karakter menjadi masalah yang sangat mendesak untuk diperbaiki. Mengapa demikian, karena bangsa Indonesia sedang mengalami krisis karakter. Oleh karena itu, Presiden Joko Widodo bertepatan dengan peringatan Hari Guru Nasional di Sentul Bogor, 27 November 2016 menekankan tentang pentingnya para guru menanamkan karakter positif kepada peserta didik. Jokowi mengatakan bahwa kita perlu mengajarkan matematika dan lain-lain kepada siswa, tapi lebih penting menanamkan kejujuran. Pendidikan karakter bukan hanya tanggung jawab guru saja, tapi juga tanggung jawab orang tua, dan masyarakat. Ketiga pihak ini harus bersinergi dan bekerjasama dalam menanamkan karakter positif kepada anak-anak. Bung Karno pernah mengatakan bahwa "Bangsa ini harus dibangun dengan mendahulukan kepentingan pembangunan karakter(character bullding), karena hal inilah yang membuat Indonesia menjadi bangsa yang besar, maju, dan jaya, serta bermartabat. Jika character building ini tidak dilakukan, bangsa Indonesia akan menjadi bangsa kuli."

Bentuk penanaman karakter positif secara menyenangkan kepada anak atau siswa adalah melalui dongeng. Pembudayaan karakter yang disandingkan dengan dongeng akan semakin menjadi renyah, asyik, dan suasana lingkungan sekolah akan semakin menggairahkan. Kemampuan mempertahankan perhatian (attention selective) merupakan suatu masalah kognisi yang mempengaruhi sebagian besar anak berkesulitan belajar. Perhatian selektif adalah kemampuan memusatkan perhatian pada suatu objek dari berbagai rangsang yang diterima (Ross dan Lerner, 1988).

Dalam mendongeng diperlukan komunikasi antara guru dan murid, walaupun pada dasarnya pada model mendongeng, anak itu pasif, hanya diam, menyimak dan mendengarkan. Bentuk komunikasi itu sendiri dapat dilakukan dengan berbagai cara, antara lain: 1. Buatlah sang tokoh beradegan menyanyi, kemudian pilihlah lagu yang sesuai dimana anak-anak sudah bisa menyanyikan, lalu ajaklah mereka bernyanyi bersama, 2. Selipkan beberapa pertanyaan dalam alur dongeng, yang mudah dijawab oleh anak, 3. Munculkan rasa sedikit penasaran pada anak dengan cara menghentikan beberapa saat jalannya dongeng atau memutus kalimat, dimana kelanjutan kalimat tersebut mudah ditebak oleh anak anak. Diharapkan dari cara-cara tersebut, secara spontan anak akan menyanyi, menjawab pertanyaan dan meneruskan sendiri kalimat 
yang terputus. Maka terciptalah suasana mendongeng yang proaktif, riang, hidup, dan tidak menjemukan.

Manfaat dari mendongeng, diantaranya: a) bagi guru, mau tidak mau harus rajin membaca untuk memperoleh cerita yang beragam dan menarik, b) bisa menambah rasa percaya diri guru dalam berakting di depan orang, c) dapat dijadikan sarana untuk mendekatkan hubungan emosional anatara guru dan murid, d) bagi murid, menambah wawasan tentang watak dan perilaku yang baik, e) menambah kemampuan / daya imajinasi anak karena cerita yang dihadirkan fiktif belaka, namun masuk akal, f) anak dilatih untuk memilih dan menentukan mana yang baik, mana yang buruk, karena pada dasarnya kebaikan pasti mengalahkan kejahatan, g) dongeng dapat berpengaruh secara cepat dan signifikan pada perkembangan watak dan perilaku anak. Maka kita sebagai pendidik harus berusaha menerapkannya dalam proses pembelajaran. Dalam konteks tersebut, kita dapat menggunakan dongeng pada semua mata pelajaran, karena pada dasarnya dongeng itu besifat fleksibel. Artinya kita dapat memasukkan segala tema ke dalam dongeng yang bisa dijadikan sebagai inti cerita dari dongeng tersebut. Apalagi saat mendongeng, kita juga boleh membuat benda mati bisa hidup, yang tidak bisa bicara menjadi bisa berbicara, hewan berperilaklu layaknya manusia, dan lain sebaginya.

Mengingat tidak terlalu sulit untuk mendongeng, maka seharusnya kita berusaha untuk mendongeng di depan anak-anak, sebagai media penanaman watak, budi pekerti, tingkah laku, dan sifat, yang bermuara pada terbentuknya karakter bangsa yang diinginkan oleh bangsa ini. Dongeng juga harus kita lestarikan sebagai budaya luhur warisan bangsa, yang implementasinya sudah jarang terlihat pada kehidupan sehari-hari. Jangan sampai anak-anak kita hanya dijejali oleh tayangan-tayangan televisi yang tidak bermutu menjelang tidur. Sungguh sangat disayangkan bila kita tidak menghadirkan dongeng di tengah gencarnya pengaruh negatif yang sedang melanda bangsa ini sebagai dampak dari kemajuan teknologi. Untuk mencegah dekadensi moral yang semakin jauh, dongeng menjadi pilihan bagi para guru dalam mentransfer karakter bangsa ke dalam benak para murid, dimana kejenuhan kadang mulai dirasakan para guru dalam berinovasi, berkreasi dan berimprovisasi dalam kegiatan belajar mengajar. Selain itu, tujuan mendongeng sebagai bentuk inovasi pembelajaran menyenangkan bagi siswa khususnya siswa SD Negeri 133 Seluma dalam belajar bahasa Indonesia.Kelebihan 
penelitian ini adalah sebagai upaya pendekatan secara langsung penanaman nilai-nilai pendidikan karakter kepada siswa dengan dongeng. Dimana dongeng lebih mudah dan lebih disenangi siswa. Siwa lebih tertarik dengan dongeng dibandingkan dengan cerita pendek ataupun lainnya.

\section{METODE PENELITIAN}

Dalam penulisan artikel ini, penulis menggunakan metode kualitatif deskriptif. Kajian diambil dari hasil observasi dan pengalaman mengajar di kelas. Teknik pengumpulan data dilakukan dengan cara observasi bahan ajar, dokumentasi, dan wawancara dengan siswa sampai pada penarikan kesimpulan bahwa materi dongeng daerah bisa dijadikan sumber belajar di SD.

\section{HASIL PENELITIAN}

Dari pengalaman peneliti di sekolah selama melakukan kegiatan proses belajar mengajar di SD Negeri 133 Seluma, belum ditemukan nilai-nilai pendidikan karakter dalam pembelajaran bahasa Indonesia. Selama proses belajar mengajar, guru lebih sering melaksanakan tugas belajar saja tanpa memperhatikan tujuan ataupun nilai pendidikan yang hendak dicapai. Guru lebih memperhatikan nilai angka dibandingkan nilai sikap yang akan didapat.

Tema yang terkandung dalam dongeng" Sayembara Pandai Tidur" yaitu ketekunan pemuda yang pndai tidur. Sedangkan amanat yang terdapat dalam cerita yaitu kita harus pandai memanfaatkan waktu luang dan tidak boleh membeda-bedakan antara si kaya dan si miskin. Nilai karakter yang ditemukan dalam dongeng tersebut adalah:

\section{Jujur}

Jujur merupakan perilaku yang didasarkan pada upaya mejadikan dirinya sebagai orang yang selalu dapat dipercaya dalam perkataan, tindakan dan pekerjaan. Berikut kutipan pada halaman 11 paragraf 20.

"Nama hamba Anak Lumang, Tuan Raja. Hamba adalah seorang pembuat bubu. Hamba tertidur pulas karena hamba kelelahan setelah bekerja keras membuat banhyak bubu, Tuan Raja”. 


\section{Disiplin}

Disiplin merupakan tindakan yang menunjukkan perilaku tertib dan patuh berbagai ketentuan dan peraturan. Karanter terlihat dari para peserta sayembara yang datang dari penjuru negeri tepat pada hari dilakukannya sayembara tersebut. Berikut kutipan pada halaman 10 paragraf 13.

"Hai penyelenggaraan sayembara pun tiba. Berpuluh-puluh pemuda datang dari berbagai penjuru negeri sambil membawa alat tidur mereka masingmasing.

Kutipan pada halaman 10 paragraf 15

Sayembara pun dimulai. Seluruh peserta segera mengambil posisi yang nyaman untuk tidur."

\section{Peduli sosial}

Peduli sosial merupakan sikap atau tindakan yang selalu ingin memberikan pertolongan pada orang lain atau masyarakat yang membutuhkan.

Berikut kutipan pada halaman 7 paragraf 3.

"Permaisuri sedih melihat putrinya yag belum juga memikirkan pernikahan, padahal ia dan Tuan Raja sudah renta. Permaisuri lalu berbicara kepada Tuan Raja sudah mulai renta. Permaisuri lalu berbicara kepada Tuan Raja Jungur untuk menjodohka Putri Serindu dengan pageran dari kerajaan seberang”.

Dari hasil analisis dongeng di atas, tergambar nilai-nilai pendidikan karakter dan sangat bermanfaat dalam kehidupan sehari-hari bagi siswa SD Negeri 133 Seluma.

\section{PEMBAHASAN}

Dalam Undang Undang Sisdiknas No. 20 Tahun 2003, Bab II pasal 3 berbunyi "Pendidikan Nasional berfungsi mengembangkan kemampuan dan membentuk watak serta peradaban bangsa yang bermartabat dalam rangka mencerdaskan kehidupan bangsa, bertujuan untuk berkembangnya potensi peserta didik agar menjadi manusia yang beriman dan bertaqwa kepada Tuhan Yang Maha Esa, berakhlak mulia, sehat, berilmu, cakap, kreatif, mandiri, dan menjadi warga negara yang demokratis serta bertanggung jawab". Maka salah satu tugas pokok pendidik adalah mencerdaskan kehidupan bangsa, dengan menanam dan menumbuhkan pewarisan nilai-nilai hidup 
sebagai suatu bangsa yang mempunyai cita-cita luhur berdasarkan Pancasila. Berkenaan dengan hal tersebut, berbagai cara harus dilakukan agar tujuan pendidikan yang ingin dicapai dan karakter bangsa yang diharapkan bisa masuk dan tertanam pada mental anak didik.

Menurut Koswara dan Halimah dalam Seluk Beluk Profesi Guru (2008), salah satu peran sentral pendidik di sekolah adalah mempromosikan soft-skill bagi para siswanya. Peranan ini tidak dapat diambil alih oleh kemajuan Teknologi Informasi yang paling canggih sekalipun. Soft skill itu sendiri meliputi: kejujuran, penghargaan, sikap toleran, kemampuan mendengar, empati, kerjasama, sikap sopan dan santun dalam berperilaku, disiplin dan kontrol diri. Hal ini hanya dapat dipromosikan oleh para pendidik yang mau peduli akan pentingnya karakter bangsa, tidak hanya dengan teknologi. Maka keistimewaan sekolah-sekolah abad 21 ada dua yaitu (a) kemampuan para pendidik menggunakan teknologi dalam pembelajaran, dan (b) kemampuan para pendidik mentransfer nilai-nilai kehidupan (living values) pada setiap peserta didik yang belajar di sekolah tersebut.

Salah satu cara penanaman soft skill tadi adalah dengan mendongeng. Tentunya kita sering mendengar bahwa tingkat minat baca anak didik kita mengalami kemerosotan. Dengan mendongeng, dimana anak pasif (hanya menyimak dan mendengarkan), memungkinkan anak, baik yang rajin maupun malas akan larut dan ikut dalam suasana mendengarkan yang baik. Untuk menambah ketertarikan anak, tentu kita sebagai pendongeng harus total memahami jalan cerita dari dongeng itu sendiri. Penampilan pendongeng yang tidak membosankan, lafal dan intonasi sesuai tokoh, serta ekspresi penjiwaan yang bisa mewakili suasana alur cerita, akan membuat anak terfokus pada dongeng tersebut.

Tradisi mendongeng yang disampaikan nenek moyang kita secara turun temurun ternyata bisa memberikan dampak yang luar biasa bagi perkembangan kepribadian anak setelah mereka dewasa. Bukan hanya itu, kebiasaan mendongeng orang tua kepada anak-anaknya sejak dini ternyata mempengaruhi kecerdasan dan pola pikir mereka, sehingga berdampak pada kemajuan negara 25 tahun ke depan (Pendidikan Karakter Melalui Dongeng, Hendri, 2013).

Dongeng adalah tradisi dan warisan umat sepanjang zaman. Hal itu menunjukkan bahwa tradisi dongeng menjadi bagian terpenting dan tidak bisa 
dipisahkan dalam kehidupan umat manusia dalam mencetak kepribadian bangsa yang lebih baik. Menurut psikolog Amerika Lawrence Kutner, "Dongeng penting bagi anak agar memasuki perjalanan hidupnya tanpa resiko. Anak bisa mengatasi masalahnya dengan mengidentifikasi diri dengan tokoh cerita."

Mendongeng atau berkisah menjadi bumbu penyedap dalam meracik sebuah bahan ajar di sekolah. Belajar sambil mendongeng, mendidik anak sambil bercerita akan membuat suasana lebih arif dan menyenangkan. Bahkan, mata pelajaran yang dianggap rumit pun akan menjadi sangat menyenangkan, apabila disampaikan melalui teknik mendongeng atau diselipi dongeng dalam belajar.

Dongeng dapat dijadikan sebagai alat atau jembatan untuk mencapai visi dan misi pendidikan karakter. Mendongeng dapat mengasah imajinasi dan fantasi anak. Ketika imajinasi dan fantasi anak terasah, maka kemampuan otak kanan dengan sendirinya akan terasah dan kinerjanya akan semakin maksimal.

Otak kanan merupakan bagian otak yang berpikir secara afektif, relasional, spiritual, kreatif, imajinatif, dan fantastik, yang berpegaruh pada sikap peduli terhadap orang lain dan lingkungan. Otak kanan yang tidak pernah diasah bisa mengakibatkan seseorang kehabisan ide, kurang rasa ingin tahu, kurang disiplin, kurang tanggung jawab, kurang menghargai orang lain, kurang menghargai keindahan, kurang menghargai kekuatan hati serta kekuatan cinta, dan lain sebagainya. Menurut Bobby de Porter, untuk menyeimbangkan otak kiri dan otak kanan, dalam pembelajaran perlu dimasukkan musik dan estetika. Semua itu menimbulkan emosi positif yang membuat otak bekerja secara efektif.

Nilai-nilai karakter dalam dongeng daerah Bengkulu yang sering muncul berdasarkan cerita yang dianalisis sebanyak tiga cerita, yaitu karakter disiplin dan peduli sosial. Oleh karena itu, karakter disiplin dan peduli sosial sangat cocok ditanamkan untuk anak jenjang menengah dan materi hikayat. Sesuai dengan pendapat Kesuma (2013) bahwa jujur dimaknai adanya kesamaan antara realitas dengan ucapan dengan kata lain apa adanya. Sedangkan, karakter peduli sosial Aunillah (2011) merupakan sikap yang berbantuk di lingkungan sekolah maupun rumah dapat memudahkan peserta didik untuk bersikap peduli terhadap lingkungan sosial yang lebih luas. Karena, sekolah dasar dinilai menjadi wadah utama dalam pembentukan karakter untuk anak. Berikut 
adalah pembahasan hasil analisis dari ke tiga nilai pendidikan, yang terdapat pada tiaptiap cerita.

Dalam dongeng "Sayembara Pandai Tidur" pada kutipan halaman 11 paragraf 20 menjelaskan, Anak Lumang memberitahukan kepada Tuan Raja tentang alasannya kenapa ia bisa tertidur pulas. Kutipan tersebut memiliki kandungan nilai jujur karena secara jelas disampaikan melalui perkataan tokoh Anak Lumang pada kalimat "hamba tertidur pulas karena hamba kelelahan setelah bekerja keras membuat banyak bubu”. Kutipan kaliat tersebut menunjukkan bahwa tokoh Anak Lumang berkata dengan sesungguhnya dan apa adanya, serta perkataannya tersebut tidak dibuat-buat olehnya. Dengan kata lain Anak Lumang tidak berbohong kepada Tuan Raja dengan mengatakan apa yang sebenarnya ia lakukan sehingga ia bisa tertidur pulas. Sesuai dengan pendapat Kesuma (2013) bahwa jujur dimaknai adanya kesamaan antara relitas dengan ucapan dengan kata lain apa adanya.

Pada kutipan halaman 10 paragraf 13 menjelaskan bahwa para pemuda yang datang dari penjuru negeri untuk mengikuti sayembara tepat pada hari dimana sayembara itu dilaksanakan. Dalam kutipan tersebut terdapat dua buah kalimat yaitu "hari penyelenggaraan sayembarapun tiba" serta kalimat "Berpuluh-puluh pemuda datang dari penjuru negeri sambil membawa alat tidur mereka masing-masing”, pada kalimat pertama menjelaskan tantang penyelenggaraan sayembara akan dilakukan pada hari tersebut sedangkan kalimat kedua menjelaskan tentang para pemuda yang taat dan patuh pada aturan dilaksanakannya sayembara, dalam hal ini adalah hari dimana sayembara tersebut akan dilaksanakan.

Kutipan tersebut memiliki kandungan nilai disiplin, karena pada kalimat kedua terdapat kata "datang" yang saling bertautan atau memiliki hubungan dengan kalimat pertama tentang hari dilaksanakannya sayembara. Kata tersebut menjelaskan tentang kataatan dan kepatuhan terhadap suatu peraturan yang telah ditetapkan. Sama halnya dengan kutipan halaman 10 paragraf 15 yang menjelaskan tentang para peserta yang patuh terhadap waktu yang telah ditetapkan untuk melaksanakan sayembara. Para peserta langsung mengambil sikap untuk melaksanakannya apa yang telah ditentukan dalam aturan sayembara ketika sayembara tersebut dimulai. Sikap untuk melaksanakan apa yang telah ditentukan, dan ketaatan merupakan salah satu ciri-ciri dari sikap disiplin. Menurut Zuriah (2008) ciri-ciri karakter disiplin adalah ketaatan, kepatuhan, 
ketertiban, kesetiaan, ketelitian, serta keteraturan perilaku seseorang terhadap norma dan aturan yang berlaku.

Kutipan pada halaman 7 paragraf 3 menjelaskan tentang keinginan dari seorang Permaisuri menginginkan anaknya untuk segera menikah karna beliau merasa putrinya sudah cukup umur untuk menikah. Permaisuri menyarankan kepada Tuan Raja agar putri mereka dijodohkan dengan seorang pangeran dari kerajaan seberang, hal tersebut dilakukan oleh permaisuri karena ia sangat peduli terhadap putrinya itu. Sehingga permaisuri ingin membantu putrinya dengan cara menjodohkan putrinya dengan pangeran dari kerajaan seberang. Sikap membantu merupakan salah satu ciri dari karakter peduli sosial. Hal tersebut sejalan dengan pendapat Novita (2014) bahwa ciriciri dan karakter peduli sosial adalah suka berbagi, membantu, dan mempermudah pihak lain dalam melakukan urusannya (urusan yang benar dan baik).

Mendongeng bisa menjadi metode penyampaian pesan-pesan moral yang sangat efektif. Bukan hanya itu, kegiatan mendongeng juga merupakan cara terbaik untuk menyegarkan proses pembelajaran agar tidak membosankan. Guru dapat menyisipkan dongeng yang berkaitan dengan mata pelajaran yang diajarkannya. Dongeng yang disampaikan dapat berupa karangan sendiri, cerita rakyat, cerita binatang baik dalam negeri maupun luar negeri. Selain itu, mendongeng dapat mendekatkan hubungan antara guru dengan peserta didik di sekolah, lebih mendekatkan hubungan cinta antara orang tua dengan anak, meningkatkan sikap kritis, meningkatkan imajinasi, meningkatkan fantasi serta menumbuhkembangkan kelembutan hati anak-anak.

Peranan dongeng dalam mendukung gerakan pendidikan karakter patut diperhitungkan dan harus terus direalisasikan dengan membiasakan kembali mendongeng, baik di sekolah maupun di rumah. Dongeng memiliki peranan penting dalam mewujudkan pendidikan karakter. Dongeng dapat menjadi jembatan komunikasi efektif dalam menyampaikan pengajaran kepada anak-anak, baik di rumah maupun di sekolah. Dongeng mampu menciptakan fantasi karena dongeng sangat dekat dan erat sekali dengan dunia imajinasi. Oleh karena itu, selektif dalam memilih dongeng merupkan faktor yang menentukan apakah anak akan berimajinasi dan berfantasi baik atau tidak. Melalui dongeng, diharapkan akan terinternaliasi karakter-karakter positif dalam membentuk kepribadian anak menjadi manusia yang berbudi pekerti luhur. 


\section{SIMPULAN}

Dongeng merupakan cerita fiktif yang berisi nasehat, pesan moral (kejujuran, kerendahhatian, kesetiakawanan, dan kerja keras), dan juga hiburan, selain itu mendongeng menjadi aktivitas berkomunikasi dengan anak yang mudah dan murah. Mendongeng juga bisa menjadi sarana efektif dalam menyampaikan pesan pada anak. Untuk itu dongeng dapat dijadikan sebagai media dalam pembelajaran apabila dalam penyampaianya memperhatikan beberapa faktor dan menggunakan media-media penunjang untuk mendukung ketersampaian pesannya, supaya pesan dan nilai-nilai moral dapat tersampaikan dengan baik dan tepat. Serta dongeng tidak lagi membosankan dan lebih menarik dalam penyampaianya.

Dongeng" Sayembara Pandai Tidur" yaitu ketekunan pemuda yang pandai tidur. Sedangkan amanat yang terdapat dalam cerita yaitu kita harus pandai memanfaatkan waktu luang dan tidak boleh membeda-bedakan antara si kaya dan si miskin. Nilai karakter yang ditemukan dalam dongeng tersebut adalah jujur, disiplin dan peduli sosial yang tinggi. Nilai-nilai karakter dalam dongeng daerah Bengkulu yang sering muncul berdasarkan cerita yang dianalisis sebanyak tiga cerita, yaitu karakter disiplin dan peduli sosial. Oleh karena itu, karakter disiplin dan peduli sosial sangat cocok ditanamkan untuk anak-anak. Nilai-nilai karakter dalam dongeng daerah Bengkulu yang sering muncul berdasarkan cerita yang dianalisis sebanyak tiga cerita, yaitu karakter disiplin dan peduli sosial. Oleh karena itu, karakter disiplin dan peduli sosial sangat cocok ditanamkan untuk anak jenjang sekolah dasar. 


\section{DAFTAR PUSTAKA}

Aunillah, Nurla Isna. (2011). Panduan Menerapkan Pendidikan Karakter di Sekolah. Yogyakarta: Laksana.

Hendri. (2013). Pendidikan Karakter Melalui Dongeng. Jakarta: Gramedia.

Kesuma, Dharma. (2013). Pendidikan Karakter, Kajian Teori dan Praktik di Sekolah. Bandung: PT. Remaja Rosdakarya.

Koswara, Deni. (2008). Seluk-Beluk Profesi Guru. Bandung: Pribumi Mekar.

Novita. (2014). Etika dan Kepribadian Kepedulian Sosial. http://novita. Artikel. Html. Diakses pada 11 April 2018.

Zuriah, Nurul. (2008). Pendidikan Moral dan Budi Pekerti: dalam Perspektif Perubahan. Jakarta: PT. Bumi Aksara.

Ross daan Lerner. (1988). Penanaman Karakter. Jakarta: PT. Gramedia.

Undang-Undang Sistem Pendidikan Nasional Nomor 20 Tahun 2003. Jakarta: Kemendikbud. 